\title{
STUDENTS' PSYCHOLOGICAL PROBLEMS IN SPEAKING: A CASE STUDY ON SPEAKING II CLASS OF STKIP PGRI BANJARMASIN
}

\author{
Ninuk Krismanti ${ }^{1}$ \\ Maria Margaretha Siregar ${ }^{2}$
}

1. Program Studi Pendidikan Bahasa Inggris STKIP PGRI Banjarmasin ninukkrismanti@ stkipbjm.ac.id (085751147199)

2. Program Studi Pendidikan Bahasa Inggris STKIP PGRI Banjarmasin monz914@gmail.com (087814041886)

\begin{abstract}
This study is intended to describe psychological problems faced by the students taking Speaking II class at STKIP PGRI Banjarmasin. The researchers believe that in learning English, students do not only have linguistic problems but also psychological problems. This study is conducted under a case study design. The instruments used in this study are questionnaires and interviews. The technique of sampling applied in this study is total population technique of sampling. 34 students are chosen as the subjects of the study. Of five psychological problems identified, it is found that there are only four prominent problems faced by the students in speaking: (1) lack of confidence, (2) fear of mistakes, (3) shyness, and (4) anxiety. Most of the students do not have problem regarding their motivation.
\end{abstract}

Keywords: psychological problem, speaking, case study.

\section{INTRODUCTION}

\section{A. Background of the Study}

The ability to speak well may be a gift for some people or problem for some others. We cannot deny that speaking in a foreign language requires not only linguistic ability on the target language but also courage. Our psychological preparedness is essential when we want to speak well with others. In relation to English speaking, as language learners, though we have learnt English for years, it is still possible for us to be reluctant in speaking it.

Students taking English as their major are not free from speaking problems. Based on the preliminary study, the researchers found that although the English Department students' exposure of English is higher compared to its exposure for students taking other majors in STKIP PGRI Banjarmasin, the students are still afraid of speaking English. This fact leads the researchers to reveal what psychological problems that hinder the students of the English Department of STKIP PGRI Banjarmasin to speak English are. 
At the English Department of this institution, speaking is taught intensively through four compulsory series. Speaking II class is designed for the second semester students of this major. In this study, Speaking II students are chosen because of two reasons. First, after participating in this study, it is hoped that it is not too late for them to realize what their psychological problems in speaking English are so that they can improve themselves in the following years. Second, Speaking II students are perfect example of how English exposure to train students' linguistic ability may not always be the warranty of how they can speak English well. Psychological factors also influence students' ability in speaking English.

\section{B. Problem Formulation}

Based on the background above, the problem formulated for this study is: "What are the psychological problems faced by students in speaking II class at the English Department of STKIP PGRI Banjarmasin Academic Year 2016/2017?”

\section{Objectives}

This study is conducted to reveal psychological problems faced by students in Speaking II class at the English Department of STKIP PGRI Banjarmasin Academic Year 2016/2017.

\section{REVIEW OF RELATED LITERATURE}

\section{A. Previous Studies}

There are some previous studies that become the references as well as the media of comparison for this study. The first study is conducted by Tanveer (2007, p. 61) entitled "Investigation of the Factors that cause language Anxiety for ESL/EFL Learners in Learning Speaking Skills and the Influence it casts on Communication in the target Language". The tool for the data collection is an interview administered to students and teachers. The main finding of the most provoking skill in L2/FL (English) learning is anxiety. Almost all research subjects acknowledged that people feel anxious and nervous while speaking English in front of others as a result of lack of self-confidence. In addition, some EFL learners even stated that they feel "stupid" when not able to speak English well and others explained that they try to escape the situation where they have to speak in front of others.

Second study is conducted by Juhana (2012) entitled "Psychological Factors That Hinder Students from Speaking in English Class (A Case Study in a Senior High School in South Tangerang, Banten, Indonesia)". From her research, it is found that the students have psychological factors such as anxiety, lack of self-confidence, and lack of motivation that hinder them from practicing their speaking in English class. To overcome these psychological problems, the students need to be motivated in order to be more confident.

The next study is conducted by Javid (2014) entitled "Measuring Language Anxiety in an EFL Context". In his study, he concluded that among four anxiety factors, communication apprehension anxiety is the biggest problem 
faced by the students followed by English classroom anxiety. Students do not feel comfortable and confident when speaking in foreign language in front of their class fellows and even worse when they have native speakers around them. The panicking factor occurs when they have to communicate in the target language without prior preparation.

In comparison, there are similarities between this study and the three previous studies above. First, all researchers set their studies believing that there are psychological problems involved in students' process of English learning as a foreign language. Second, the main instrument used for the previous studies and this study is questionnaire. On the other hand, this study is different from the previous studies because in this research, the focus is not only anxiety but also four other physiological problems. Moreover, the location and samples of this study are different from the previous ones.

\section{B. Psychological Problems in Speaking}

In this study, as explained previously, the psychological problems becoming the focus of the study are lack of confidence, lack of motivation, shyness, fear of mistakes, and anxiety. All these psychological factors are interrelated to each other.

\section{Lack of Confidence}

Self-confidence is one of the most influential factors affecting learning. Dornyei (2005) stated, "the concept of self-confidence is closely related to selfesteem, both share a common emphasis on the individual's perception of his or her abilities as a person." They argued that self-confidence formed during a childhood and it is a combination of interpersonal and intrapersonal experiences. Additionaly, He and Chen as cited in Juhana (2012, p. 102) stated that low ability in speaking English is the main cause of students' low confidence. Students do not have confidence and feel bad when they can not speak English well. According to Brown (2001), the teacher also influences students' confidence in speaking. The teacher who does not give encouragement to his/her students can possibly make students have low confidence when speaking English.

\section{Lack of Motivation}

Zua in Juhana (2012, p. 103) argued that motivation is a basic part in learning activities. Through motivation, students' interest in learning will be enhanced. From the opinion from the experts, the researchers believe that motivation shall be one of the indicators determining a successful communication. Thus, motivation given by the teacher toward the students makes them able to speak English better.

\section{Shyness}

Shyness refers to an emotional thing that many students suffer from when they must speak in class. This indicates that shyness can be a source of problem in students' learning activities, especially in the class of speaking. Saurik in Juhana 
(2011, p. 101) mentioned that most of English students feel shy when they speak the language because they think they will make mistakes when they talk. They are also afraid of being laughed at by their peers. Nobody wants to sound stupid in front of other people. Thus, instead of trying, shy people tend to keep silent than embarrassing themselves.

\section{Fear of Mistake}

As argued by many experts, fear of mistake becomes one of the main factors of students' reluctance to speak English in the classroom. Ur (2009) stated that one reason why learners are often worried to even try to speak in a foreign language is their fear of making mistakes. None of the students wants to look bad and foolish in front of the audiences or their classmates. Therefore, it is important for teachers to convince their students that making mistakes is not a wrong or bad thing because students can learn from their mistake.

\section{Anxiety}

According to Oxford Advanced Learner's Dictionary (2013), anxiety is a feeling or worried that something bad is going happen. It is considered as one of the most common psychological problems affecting students' foreign language learning. This statement is in line with Brown (2001, p. 269) who stated, "one of the major obstacles learners have to overcome in learning to speak is the anxiety generated over the risks of blurting things out that are wrong, stupid, or incompressible". When students are anxious, their speaking performance will be influenced. In some cases, anxiety leads no nervous breakdown where students are able to speak nothing at all.

\section{METHODOLOGY}

\section{A. Design}

This study is a case study aiming to explain the phenomena of psychological problems the students face in their Speaking class. According to Yin (2013), a case study has three inquires: (1) it copes with distinctive situation with many interest variables; (2) it relies on multiple sources of evidence by using triangulation method; (3) it applies prior theories from other researchers to guide data collection and data analysis.

\section{B. Location}

This research is conducted in STKIP PGRI Banjarmasin located at Jalan Sultan Adam Kompleks H. Iyus RT. 23 No. 18 Banjarmasin. The data are taken from the Speaking II class of the English Department of the campus. The location is chosen because when observing the class during the preeliminary study, the researchers assumed that the students have not only linguistic problems but also psychological ones that hinder them from speaking. 


\section{Instrument}

In this research, the reseachers use two instruments: questionnaires as the main instrument, and interview as the supplementary instrument. The questionnaires in this research are adapted from Ur (2009) and Juhana (2012). The questionnaires consist of 15 statements. The distribution of each psychological problem is as follow:

Table 1. Test item distribution

\begin{tabular}{|l|l|l|}
\hline No. & Type of Psychological Problem & Number of Test Items \\
\hline 1. & Lack of Confidence & $1,2,3$ \\
\hline 2. & Lack of Motivation & $4,5,6$ \\
\hline 3. & Shyness & $7,8,9$ \\
\hline 4. & Fear of Mistakes & $10,11,12$ \\
\hline 5. & Anxiety & $13,14,15$ \\
\hline
\end{tabular}

To validate the data, the researchers use triangulation method through the use of another instrument which is interview. The interview is also used to dig the information deeper from the students regarding the psychological problems they face in their Speaking class.

\section{Population and Sampling}

According to Gray et. al. (2007, p. 103), "the term used to describe all the possible cases of interest is the population." The population in this research is all active students in the second semester of the English Department of STKIP PGRI Banjarmasin taking Speaking II class. There are total 34 students as the population of the study. Because the number of students becoming the population is less than a hundred, the researchers use total sampling technique to gather the data.

\section{E. Data Analysis}

There are three steps taken in data analysis of this study. The three steps are adopted from Miles and Huberman (1994, pp. 10-12):

1) Data reduction

Data reduction refers to the process of choosing and simplifying the data. The researcher reduced the data from the interviews because not all information given by the respondents is taken into account for this study. For the questionnaires, all information obtained is taken into analysis.

2) Data display

Based on the collected and reduced data, the researchers display the data in the forms of tables before narrating them. Data display helps the researchers draw the conclusions of the study.

3) Conclusion drawing 
After displaying the data, the researchers draw conclusions of the study. These conclusions are the highlight of what physiological problems becoming the biggest obstacles for students in their Speaking II class.

\section{FINDINGS AND DISCUSSIONS}

\section{A. Findings}

The findings are drawn from the data collected from the questionnaires and interviews. The findings on each psychological problem are presented below:

\section{Lack of Confidence}

The test items containing questions on lack of confidence in questionnaires are found in questions number 1,2, and 3.

Table 2. Result of the analysis of lack of confidence

\begin{tabular}{|c|l|c|c|c|c|c|c|}
\hline \multirow{2}{*}{ No } & \multicolumn{2}{|c|}{ Statement } & \multicolumn{3}{|c|}{ Frequency } & \multicolumn{3}{c|}{ Percentage (\%) } \\
\cline { 3 - 8 } & Yes & No & Total & Yes & No & Total \\
\hline 1. & $\begin{array}{l}\text { I speak English fluently } \\
\text { with my English teacher }\end{array}$ & 7 & 27 & 34 & $20.58 \%$ & $79.41 \%$ & $100 \%$ \\
\hline 2. & $\begin{array}{l}\text { I speak English well } \\
\text { with my classmates. }\end{array}$ & 12 & 22 & 34 & $35.29 \%$ & $64.70 \%$ & $100 \%$ \\
\hline 3. & $\begin{array}{l}\text { I speak English well in } \\
\text { front of the audiences. }\end{array}$ & 11 & 23 & 34 & $32.35 \%$ & $67.64 \%$ & $100 \%$ \\
\hline
\end{tabular}

Based on the table 2 above, for question number 1, 7 (20.58\%) students answered "Yes", and $27(79.41 \%)$ students answered "No". From this result, it can be concluded that more than half of students in Speaking II class still have difficulty to speak English fluently with their English lecturer.

For question number 2, 12 students (35.29\%) answered "Yes", and 22 $(64.70 \%)$ students answered "No". From this result, the researchers concluded that most of students in Speaking II class rarely speak English well with their classmates.

For question number 3, $11(32.32 \%)$ students answered "Yes", and 23 $(67.64 \%)$ students answered "No". From this result, the researchers concluded that more than half of students in Speaking II class still have difficulty to speak English well in front of the audiences.

\section{Lack of Motivation}

The test items containing questions on lack of motivation in questionnaires are found in questions number 4,5 , and 6 . 
Krismanti. N \& Siregar. M.M / LENTERA Jurnal Ilmiah Kependidikan

Vol. 12 No.2 (2017) 62-73

Table 3. Result of the analysis of lack of motivation

\begin{tabular}{|c|l|c|c|c|c|c|c|}
\hline \multirow{2}{*}{ No } & \multicolumn{1}{|c|}{ Statement } & \multicolumn{3}{|c|}{ Frequency } & \multicolumn{3}{c|}{ Percentage (\%) } \\
\cline { 2 - 7 } 4. & $\begin{array}{l}\text { Yes } \\
\text { I try to find out how to } \\
\text { improve my English } \\
\text { accent. }\end{array}$ & 26 & 8 & 34 & $76.47 \%$ & $23.52 \%$ & $100 \%$ \\
\hline 5. & $\begin{array}{l}\text { I think I will speak } \\
\text { perfect English } \\
\text { someday. }\end{array}$ & 12 & 22 & 34 & $35.29 \%$ & $64.70 \%$ & $100 \%$ \\
\hline 6. & $\begin{array}{l}\text { I am always motivated } \\
\text { when learning English } \\
\text { course. }\end{array}$ & 21 & 13 & 34 & $61.76 \%$ & $38.23 \%$ & $100 \%$ \\
\hline
\end{tabular}

Based on the table 3 above, for question number 4, $26(76.47 \%)$ students answered "Yes", and $8(23.52 \%)$ students answered "No". From this result, the researchers concluded that almost all students in Speaking II class try to find out how to improve their English accent.

For question number 5, $27(79.41 \%)$ students answered "Yes", and 7 $(20.58 \%)$ students answered "No". Therefore, from that result, almost all students in Speaking II class think that they will speak perfect English someday, but some students (7 students) do not think the same way.

For question number 6, the researchers concluded that $21(61.76 \%)$ students answered "Yes" and $13(38.23 \%)$ students answered "No". From this finding, it can be concluded that students in Speaking II class are always motivated when learning English course although 13 students feel that sometimes they are not motivated when learning English.

\section{Shyness}

The test items containing questions on shyness in questionnaires are found in questions number 7,8 , and 9 .

Table 4. Result of the analysis of shyness

\begin{tabular}{|c|l|c|c|c|c|c|c|}
\hline \multirow{2}{*}{ No } & \multicolumn{2}{|c|}{ Statement } & \multicolumn{3}{|c|}{ Frequency } & \multicolumn{3}{c|}{ Percentage (\%) } \\
\cline { 3 - 8 } & & Yes & No & Total & Yes & No & Total \\
\hline 7. & $\begin{array}{l}\text { I am not afraid of starting } \\
\text { a conversation in English. }\end{array}$ & 25 & 9 & 34 & $79.52 \%$ & $26.47 \%$ & $100 \%$ \\
\hline 8. & $\begin{array}{l}\text { I do not feel shy when } \\
\text { speaking English. }\end{array}$ & 13 & 21 & 34 & $38.23 \%$ & $61.76 \%$ & $100 \%$ \\
\hline 9. & $\begin{array}{l}\text { I am not afraid of speaking } \\
\text { English in public places. }\end{array}$ & 16 & 18 & 34 & $47.05 \%$ & $52.94 \%$ & $100 \%$ \\
\hline
\end{tabular}

Based on table 4 above, for question number 7, 25 (79.52\%) students answered "Yes", and 9 (26.47\%) students answered "No". From this result, the 
researchers concluded that around 9 students in Speaking II class still have difficulty to start conversation in English with other people, and half of them (around 25 students who answered "Yes") are not afraid to start conversation with other people.

For question number 8, 13 students (38.23\%) answered "Yes", and 21 students $(61.76 \%)$ answered "No". From this result, the researchers concluded that almost all students in Speaking class II feel shy when they speak English with other people.

For question number 9, 16 students (47.05\%) answered "Yes", and 18 students $(52.94 \%)$ answered "No". From this result, it can be concluded that half of students in Speaking II class still have fear to speak English in public places.

\section{Fear of Mistakes}

The test items containing questions on fear of mistakes in questionnaires are found in questions number 10,11, and 12 .

Table 5. Result of the analysis of fear of mistakes

\begin{tabular}{|c|l|c|c|c|c|c|c|}
\hline \multirow{2}{*}{ No } & \multicolumn{1}{|c|}{ Statement } & \multicolumn{3}{|c|}{ Frequency } & \multicolumn{3}{c|}{ Percentage (\%) } \\
\cline { 2 - 7 } 10. & $\begin{array}{l}\text { I am afraid of making } \\
\text { mistakes while speaking } \\
\text { English. }\end{array}$ & 26 & 8 & 34 & $76.47 \%$ & $23.53 \%$ & $100 \%$ \\
\hline 11. & $\begin{array}{l}\text { I am not always afraid of } \\
\text { forgetting my speech. }\end{array}$ & 17 & 17 & 34 & $50 \%$ & $50 \%$ & $100 \%$ \\
\hline 12. & $\begin{array}{l}\text { I feel confused when I } \\
\text { miss words while speaking } \\
\text { English. }\end{array}$ & 29 & 5 & 34 & $82.29 \%$ & $14.70 \%$ & $100 \%$ \\
\hline
\end{tabular}

Based on table 5, for question number 10, 26 (76.47\%) students answered "Yes", and $8(23.52 \%)$ students answered "No". From this result, the researchers concluded that almost all students in Speaking II class are still afraid to make mistakes while speaking English.

For question number 11, 17 (50\%) students chose "Yes", and 17 (50\%) students chose "No". It can be concluded that half of students in Speaking II class still have problem when they forget their speech although another half of students answered that they are not afraid of forgetting their speech.

For question number 12, 29 (85.29\%) students answered "Yes", and 5 $(14.70 \%)$ students answered "No". From this result, the researchers concluded that almost all students still have difficulty and feel confused when they are missing words while speaking English.

\section{Anxiety}

The test items containing questions on anxiety in questionnaires are found in questions number 13, 14, and 15 . 
Table 6. Result of the analysis of anxiety

\begin{tabular}{|c|l|c|c|c|c|c|c|}
\hline \multirow{2}{*}{ No } & \multicolumn{1}{|c|}{ Statement } & \multicolumn{3}{|c|}{ Frequency } & \multicolumn{3}{c|}{ Percentage (\%) } \\
\cline { 2 - 7 } 13. & $\begin{array}{l}\text { Yes } \\
\text { I feel nervous when } \\
\text { someone is speaking } \\
\text { English to me. }\end{array}$ & 21 & 13 & 34 & $61.76 \%$ & $38.23 \%$ & $100 \%$ \\
\hline 14. & $\begin{array}{l}\text { I get nervous when } \\
\text { speaking English during } \\
\text { lectures. }\end{array}$ & 29 & 5 & 34 & $85.29 \%$ & $14.70 \%$ & $100 \%$ \\
\hline 15. & $\begin{array}{l}\text { I feel sure and relaxed } \\
\text { when speaking English. }\end{array}$ & 11 & 23 & 34 & $32.35 \%$ & $67.64 \%$ & $100 \%$ \\
\hline
\end{tabular}

Based on the table 6, for question number 13, $21(61.76 \%)$ students answered "Yes", and 13 (38.23\%) students answered "No". From this result, the researchers concluded that almost all students still feel nervous when someone is speaking English to them, and just a few students feel confident to have conversations in English with other people.

For question number 14, 29 (85.29\%) students answered "Yes", and 5 (14.70\%) students answered "No". It can be concluded that almost all students are still nervous when speaking English during the lectures. It means that they have difficulty to speak English when studying in the classroom.

For question number 15, $11(32.35 \%)$ students answered "Yes", and 23 $(67.64 \%)$ students answered "No". From this result, it can be concluded that students in Speaking II are not sure and cannot be relaxed when speaking English.

\section{B. Discussions}

When comparing the data found in this study to all psychological problems mentioned in the theories, it can be concluded that the findings are in line with the theories. According to Ur (2009), there are several psychological problems in speaking such as (1) inhibition, worried about making mistake, fearful of criticism or losing face, or simply shy of the attention that their speech may attract, (2) nothing to say or having no motivation to express self. Moreover, according to Juhana (2012), the most common psychological problems that hinder students from speaking are: (1) lack of confidence, (2) lack of motivation, (3) fear of mistake, (4) shyness, and (5) anxiety. All the findings of this study cover the psychological problems the students face as stated by the experts.

\section{Lack of Confidence}

In terms of confidence, it can be concluded that almost all students in Speaking II class still have problem with their self-confidence when speaking English with their lecturer, their classmates, and when speaking in front of the audiences. Almost all students in Speaking II class do not speak English fluently with their English lecturer because of their lack of confidence. Sometimes, they 
feel afraid to start a conversation; they also said that they feel confused how to respond their lecturer when being asked in English.

Speaking class II students also do not speak English well with their classmates. From the interviews, most of them said that they do not use English with their classmates because they feel more comfortable using their mother tongue (Banjarese language). They also said that sometimes their friends do not understand the conversation if they speak in English language.

Moreover, almost all students in Speaking II class also have problem when they want to speak English in front of the audiences. Their poor fluency makes them unconfident. This confidence problem leads to the students' reluctance in speaking English.

\section{Lack of Motivation}

Based on the data, students in Speaking II class do not have lack of motivation problems when studying English although some students admit that they do not try hard because they are too lazy to find out how to improve their ability. Most of students claimed that they are trying to improve their English accent by watching movies or listening to the music. They also read some books, magazines, or articles in English. They are trying to improve their English because they want to look good when speaking English with other people. Almost all students have a positive opinion that someday they will be better in English. However, there are 7 students who have an opposite opinion. It is because they have a unique accent from their region that they regard as an obstacle when speaking English. Another reason is because they are too lazy to study outside the classroom.

In addition, almost all students in Speaking II class are always motivated when learning English course. They are motivated because they want to improve their English. They are also motivated because they want to increase their vocabularies. However, there are 13 students who claimed that sometimes they are not motivated to learn English. They feel bored and not interested in several subject materials, or they are not interested with the lecturer. This is in line with Juhana (2012) who stated that sometimes students are lack in motivation because of the teacher's way of teaching.

\section{Shyness}

In terms of shyness, the researchers concluded that several students in Speaking II class have shyness problem. The students who are not afraid to start conversation in English said that sometimes they feel courageous to initiate a conversation in English with their peers. On the other hand, some other students said that that they feel shy to start a conversation especially in English because they have no courage to do so. Students' shyness of speaking English comes from their fright of making mistakes, their limited vocabularies, and their fluency in English.

\section{Fear of Mistakes}


Based on the analysis, the researchers concluded that students in Speaking II class also have fear to make mistakes while speaking English. The main cause is their worrisome of getting negative responses from their peers. They are worried that they will be mocked by their friends when saying wrong words or mispronounce something. Even worse, the students are afraid of forgetting or losing words when speaking. They feel confused and panic when it happens. They are also afraid that their peers will make fun of them. They do not want to sound silly in front of their friends. In many cases, lecturer's negative feedbacks toward students' mistakes make everything worse.

\section{Anxiety}

Most of students in Speaking II class also feel anxious when they speak English. They feel nervous and are not relaxed when speaking English. They are worried that they cannot answer their speaking opponent(s) because of their limited vocabularies. Sometimes, they are also confused because they do not understand the conversation. They are also worried if their opponent(s) cannot understand what they are saying.

In classroom setting, the researchers found that most students get nervous when speaking English during the lectures. The students suddenly feel nervous when they speak in front of their classmates. Sometimes, when the anxiety hits them, they cannot convey their thought. The students are also afraid and become nervous of making the same mistakes in pronunciation over and over again.

\section{CONCLUSIONS}

Based on the analysis presented previously, some conclusions that can be drawn are as follows:

1. The prominent psychological problems faced by students in Speaking II class at the English Department of STKIP PGRI Banjarmasin are: (1) lack of confidence, (2) fear of mistakes, (3) shyness, and (4) anxiety.

2. The students in Speaking II class do not have lack of motivation problem because from the result of the questionnaires and the interviews, most of them are still motivated when learning English, and they keep trying to improve their English. The students are also motivated that someday they will be able to speak English perfectly someday.

\section{REFERENCES}

Brown, H. Douglas. 2001. Teaching by Principles: An Interactive Approach to Language Pedagogy (Second Edition). New York: Longman.

Dornyei, Z. 2005. The Psychology of Language Learner: Individual differences in Second Language Acquisition. Routledge.

Grey, Paul S., et al. 2007. The Research Imagination: An Introduction to Qualitative and Quantitative Methods. New York: Cambridge University Press. 
He, Summer X and Chen Amanda J.Y. 2010. How to Improve Spoken English. in Juhana. 2012. Psychological Factors That Hinder Students from Speaking in English Class (A Case Study in a Senior High School in South Tangerang, Banten, Indonesia). The Internet Journal of Education and Practice Vol.03, N0.12. Retrieved on: 23 November 2016.

Javid, Choudhary Zahid. 2014. Measuring Language Anxiety in an EFL Context. The Internet Journal of Education and Practice Vol. 5, No.25. Retrieved on: 23 November 2016.

Juhana. 2012. Psychological Factors That Hinder Students from Speaking in English Class (A Case Study in a Senior High School in South Tangerang, Banten, Indonesia). The Internet Journal of Education and Practice Vol.03, N0.12. Retrieved on: 23 November 2016.

Miles, Matthew B. and A. Michael Huberman. 1994. An Expanded Sourcebook Qualitative Data Analysis Second Edition. California: Sage Publications.

Saurik. 2011. Learning English the Easy Way!. In Juhana. 2012. Psychological Factors That Hinder Students from Speaking in English Class (A Case Study in a Senior High School in South Tangerang, Banten, Indonesia). The Internet Journal of Education and Practice Vol.03, N0.12. Retrieved on: 23 November 2016.

Tanveer, Muhammad. 2007. Investigation of the factors that cause language anxiety for ESL/EFL learners in learning speaking skills and the influence it casts on communication in the target language. Unpublised Dissertation. United Kingdom: University of Glasgow.

Ur, Penny. 2009. A Course In Language Teaching: Practice and Theory. United Kingdom: Cambridge University Press.

Yin, Robert K. 2013. Case Study Research: Design and Methods Second Edition. London: SAGE Publications.

Zua, Li. 2008. Exploring the Effective Factors Influencing Teaching of Spoken English. In Juhana. 2012. Psychological Factors That Hinder Students from Speaking in English Class (A Case Study in a Senior High School in South Tangerang, Banten, Indonesia). The Internet Journal of Education and Practice Vol.03, N0.12. Retrieved on: 23 November 2016. 